\title{
Exclamatives as responses at the syntax-pragmatics interface
}

\author{
Andreas Trotzke ${ }^{\mathrm{a}, \mathrm{b},{ }^{*}, \text { Xavier Villalba }}{ }^{\mathrm{c}}$ \\ a University of Konstanz, Department of Linguistics, Universitätsstraße 10, Konstanz, 78457, Germany \\ b Universitat Autònoma de Barcelona, Center for Theoretical Linguistics (CLT), Facultat de Lletres, Edifici B, Bellaterra (Barcelona), 08193, \\ Spain

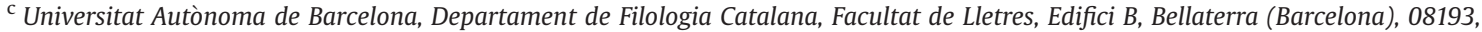 \\ Spain
}

Keywords:

Catalan

Exclamatives

Experimental pragmatics

German

Responses

Syntax-pragmatics interface

\section{A B S T R A C T}

In this paper, we explore exclamatives when used as responses in a discourse. Our proposal is based on the following pragmatic observation: so-called that-exclamatives in both Germanic and Romance languages are preferred as responses to polar questions, while wh-exclamatives are restricted to a response use in non-polar contexts. We establish this data pattern empirically by means of two judgment studies, and we then provide a detailed theoretical account for these challenging new data points. In particular, we show that the differences between the response uses of wh-exclamatives and that-exclamatives can be explained on syntactic grounds, analogous to 'the syntax of answers' proposed in recent syntactic work by Holmberg $(2013,2015)$ at the syntaxpragmatics interface. In sum, we provide a pragmatically more refined view on exclamatives and their use in a discourse, suggesting new empirical distinctions at the syntax-pragmatics interface.

\section{Introduction}

Many languages of the world feature wh-exclamatives (e.g., How fast he was!), and some of them also exhibit that-configurations that can be used as root clauses expressing an exclamatory speech act; the Germanic languages Dutch (1a), German (1b), and Swedish (1c) are prominent and well-documented examples (e.g., Bennis, 1998; d'Avis, 2016; Delsing, 2010):

\footnotetext{
* Corresponding author.

E-mail addresses: andreas.trotzke@uni-konstanz.de (A. Trotzke), xavier.villalba@uab.cat (X. Villalba).
} 
(1) a. Dat hij die boeken kan lezen! [Dutch]

that he those books can read

'Wow, he can read those books!'

b. Dass er diese Bücher lesen kann! [German]

that he those books read can

'Wow, he can read those books!'

c. Att du hann till mötet! [Swedish]

that you reached to meeting.DEF

'What a surprise that you reached the meeting!'

However, Romance languages feature that-exclamatives as well; observe the following examples from Catalan (2a) and French (2b); see Villalba (2003) and Gérard-Naef (1980): ${ }^{1}$
n'és, de car!
[Catalan]
that of.it-is of expensive
'How expensive it is!'

b. Que cette histoire est obscure! [French]
that this story is dark

'How dark this story is!'

All these constructions share a rich array of features at the syntactic, semantic, and pragmatic level, which we cannot detail in this paper (see Trotzke and Villalba, in press). However, and just to highlight the most important ones, we would like to mention here that they all involve a declarative complementizer, are restricted to matrix contexts, involve an exclamative interpretation, and, as we will discuss at length in this paper, fulfill similar discourse functions. Even though each similarity might be due to chance when considered in isolation, we think that the combination of such a cluster of similarities is evidence enough to propose a unified analysis.

In this paper, we will compare wh- and that-exclamatives in Germanic and Romance languages and introduce an observation that has not been accounted for so far: $w$ h- and that-exclamatives behave differently when used as responses in a discourse. We use 'responses' as a broad category that encompasses direct answers to information-seeking questions, but also contains other second moves in a dialogue that provide the information asked for in a preceding question in more indirect ways (e.g., by means of pragmatic inferencing/implicatures; see Holtgraves, 1998; Walker et al., 2011; de Marneffe and Tonhauser, 2019). This will become clear at several points of our paper, but for now observe the following example, which inspired our investigation into comparing wh- and that-exclamatives as responses. The following data point has been pointed out for Catalan, but only as a side issue and in passing (examples from Castroviejo Miró, 2006: 192):

The data in (3) indicate that Catalan that-exclamatives (3B) can be used as a felicitous response to a polar question, while the corresponding wh-exclamative (3B') would be pragmatically odd. Note that both cases could in principle be indirect ways

\footnotetext{
${ }^{1}$ We hasten to point out that there is a lot more to say about the morphosyntax of the construction we refer to as that-exclamatives. For instance, such configurations have been discussed as cases of 'insubordination' in the literature and/or pointed out in the context of 'illocutionary' complementizers (Evans, 2007; Truckenbrodt, 2006; Gras and Sansiñena, 2017; D'Hertefelt, 2018; Corr, 2018; Ceong, 2019; and many more). However, a cross-linguistic discussion of those claims and analyses and how they relate to our comparison between Catalan and German would take as too far afield in this paper. For instance, we believe that only German and not also Catalan that-exclamatives are proper instances of 'insubordination', and there is some (recent) literature supporting this claim (see Villalba, 2003; Feldhausen and Villalba, 2020; and Trotzke and Villalba, in press for arguments that Catalan thatexclamatives cannot be subordinated, which is also a general consensus in Catalan grammars). Since in the present paper, we instead explored the discourse use of exclamatives introduced by the complementizer that (and not their detailed morphosyntactic structure), we would like to refer the reader to our other work and the typological literature on insubordinated structures like that-exclamatives cited above.
} 
(3) A: Saps res de l'Antonio?

'Have you heard from Antonio?'

B: Que en fa de temps que no el veig!
that of.it does of time that NEGhim see.I

'I haven't seen him for such a long time!' (= No, I haven't heard from Antonio.)

B': \# Quant de temps que fa que no el veig!
how.much of time that makes that NEG him see.I

'How long it has been since I have last seen him!' (= No, I haven't heard from

Antonio.)

to answer the question (according to our terminology: responses), meaning that from both (3B) and (3B') the hearer can infer the answer 'No (I haven't heard from Antonio)'. However, there is a clear contrast in pragmatic felicity between (3B) and (3B'), which has been pointed out by Castroviejo Miró (2006), but remains unexplained in her and previous accounts. The present article is based on the hypothesis that this interesting contrast can actually shed some light on the interaction between the syntax that is involved in the configurations in (3) and their pragmatics in a dialogue. We will add further empirical support to observations like (3) and try to account for these data theoretically.

The paper is structured as follows. In Section 2, we will first introduce our hypothesis that the acceptability pattern in (3) depends on the respective discourse context (i.e., the type of question preceding the exclamative). Crucially, we will then demonstrate that these dependencies hold beyond more than one language by reporting on two parallel judgment studies, one on Catalan and one on German, thereby allowing for a comparison between a Romance and a Germanic language. After presentation of our empirical study, Section 3 discusses our results on the discourse properties of wh-and that-exclamatives and their dependency on different types of preceding question speech acts. We will connect our findings to the literature on the socalled 'syntax of answers' (Holmberg, 2013, 2015; Haegeman and Weir, 2015; Wiltschko, 2018; Espinal and Tubau, 2019), and we propose a detailed analysis for the syntax-pragmatics properties of wh- and that-exclamatives. Section 4 summarizes and concludes the paper and points out broader implications that go beyond the empirical domain of exclamatives.

\section{A cross-linguistic study on exclamatives as responses}

Let us look at our key example (3) again. As we have already pointed out in Section 1, this minimal pair suggests that thatexclamatives (at least in Catalan) can be used as a felicitous response to a polar question ('Have you heard from Antonio?'), while the corresponding wh-exclamative would be pragmatically odd.

One is tempted to look at the difference in (3) from the perspective of the respective exclamative forms only. That is, one hypothesis could be that that-exclamatives are always (i.e., in any type of discourse) more acceptable than wh-exclamatives when used as responses to a question because of their different linguistic form. This way to look at the data is in accordance with most of the previous literature on exclamatives, which has mainly focused on the type of responses (e.g., different forms of exclamatives vs. declarative assertions; see Grimshaw, 1979; Zanuttini and Portner, 2003; and many others).

In contrast to those accounts, we would instead like to explore the type of questions and thus the type of discourse the exclamatives occur in. This is a perspective to account for data like (3) above that has not been taken so far, and this new approach opens the path for hypotheses according to which (i) the that-exclamative in (3) might be better because it is used as a response to a polar question ('Have you heard from Antonio?'), and (ii) wh-exclamatives might not be so bad when we also take into account non-polar questions as preceding utterances (e.g., 'When have you heard something from Antonio?'). All in all, our study focused on the form of the preceding discourse-a factor that is often neglected in the literature on exclamatives. Crucially, we tested this discourse factor (i.e., preceding utterance is either a polar or a non-polar question) across two languages that both feature whexclamatives as well as that-exclamatives: Catalan and German. In other words, since we did not only test the original Catalan observation sketched above, our study potentially also allows for some cross-linguistic conclusions. Let us now turn to the two judgment studies where we tested dialogues like in (3) for both Catalan and German.

\subsection{Materials and participants}

The experimental items for both languages were presented online as a randomized written questionnaire via the platform SoSci Survey (https://www.soscisurvey.de) and were manipulated at two levels: Exclamation form (i.e., that-exclamative [4], whexclamative [5]) and DISCOURSE CONTEXT (i.e., the question preceding the exclamation was either a polar or a non-polar question). Note at this point that in what follows we use the term 'exclamation' for referring to the relevant expressive speech act of 
expressing surprise, which is a pragmatic concept clearly defined and discussed in the semantics/pragmatics literature (e.g., Rett, 2011). By contrast, we use 'exclamative' for the concrete syntactic forms an exclamation speech act can be performed with. Crucially, while the speech act 'exclamation' is a universal pragmatic concept across languages, the respective syntactic forms (exclamatives) are of course not and thus subject to language-specific variation (e.g., d'Avis, 2016). This distinction is particularly relevant for our study because for both languages, we also included declarative exclamations (= declarative syntax used as an exclamation speech act; see [6]) because we wanted to test whether the data we get for (4) and (5) are in some way unique to the respective sentence types, or whether either (4) or (5) patterns with declarative exclamations; for the full set of items, see Appendix A. ${ }^{2}$

For each combination, there were four examples. To test whether participants understood the task of judging the minidialogues, we constructed four fillers we expected to get good judgments ('good' fillers), four fillers we expected to get bad judgments ('bad' fillers), and four fillers we expected to receive mixed judgments ('medium' fillers); see Appendix B. This methodology has already been proven to be useful in a previous study in experimental pragmatics (Trotzke, 2019). Taken together, there were 36 stimuli in total; stimuli were divided into 2 lists, each consisting of 24 items. All items were designed in a strictly parallel fashion for the two languages (Catalan and German), but we also ensured that the items sounded most natural in the respective language by our choice of language-specific names, interjections, etc.

\section{that-exclamative:}

(4) $[$ German $]$

Julia spricht mit Marc über alte Freunde aus der Schulzeit. ('Julia is talking to Marc about some old friends from their school days.')

Julia: [POLAR] „Hast Du in letzter Zeit mal von Hans gehört?“' ('Have you heard from Hans recently?') vs. [NON-POLAR] „Wann hast Du eigentlich das letzte Mal etwas von Hans gehört?“' ('When have you heard something from Hans last time?')

Marc: „Ach der Hans! Dass ich ihn so lange nicht gesehen habe!“ ('Lordy, Hans! How long it has been since I have last seen him!')

(4') [Catalan]

La Júlia parla amb el Marc sobre alguns vells amics de l'escola. ('Júlia is talking to Marc about some old friends from their school days.')

Júlia: [POLAR] “Saps alguna cosa del Joan?” ('Have you heard from Joan recently?') vs.

[NON-POLAR] “Quan vas saber alguna cosa del Joan?” ("When have you heard something from Joan last time?')

Marc: "E1 Joan, redeu! Que en fa de temps que no el veig!” ('Lordy, Joan! How long it has been since I have last seen him!')

\footnotetext{
2 Our items representing declarative exclamations-just like the other conditions-included discourse-initial markers of (either positive or negative) surprise such as 'Oh my god!', see Catalan and German versions below. Together with the respective contexts, we hypothesize that those markers sufficed to indicate an exclamation reading to our participants. Since further cues vary across the two languages under investigation (e.g., only German features exclamative modal particles; see Bayer and Trotzke, 2015; Trotzke, in press for examples and discussion) and since our study was a written questionnaire, we did not include other cues such as intonation or particles.
} 
wh-exclamative:

(5) [German]

Karl hat einen neuen Boss auf der Arbeit und unterhält sich mit einem seiner Kollegen.

('Karl has a new boss at work and is talking to one of his colleagues.')

Kollege: [POLAR] „Macht Dein neuer Boss einen guten Eindruck?““ ('Does your new boss make a good impression?') vs. [NON-POLAR] „Was für einen Eindruck macht Dein neuer Boss?“('What kind of impression does your new boss make?').

Karl: „Mein Gott! Wie gemein dieser Kerl ist! ('My God! How mean this guy is!')

(5') [Catalan]

El Carles té un nou cap a la feina i parla amb un dels seus companys. ('Carles has a new boss at work and is talking to one of his colleagues.')

Company: [POLAR] "T'ha fet bona impressió el nou cap?" ('Does your new boss make a good impression?') vs. [NON-POLAR] “Quina impressió t'ha fet, el nou cap?" ('What kind of impression does your new boss make?')

Carles: “Déu meu! Que mesquí que és aquest paio!” ('My God! How mean this guy is!') 
declarative exclamation:

(6) [German]

Fabian ist aufgefallen, dass sich Ulis Freund Thomas irgendwie verändert hat. ('Fabian noticed that Uli's friend Thomas has somehow changed.')

Fabian: [POLAR] „Ist mit Thomas irgendetwas Neues passiert?“ ('Has anything new happened to Thomas?') vs. [NON-POLAR] „Was ist mit Thomas denn los in letzter Zeit?“

('What is going on with Thomas recently?')

Uli: „Mein Gott! Er ist so glücklich, seit er eine neue Freundin hat!“('Oh my god! He is so happy since he has a new girlfriend!')

(6’) [Catalan]

El Jordi s'ha adonat que el Tomàs, l'amic del Pol, està canviat. 'Jordi noticed that Pol's friend Tomàs has somehow changed.')

Jordi: [POLAR] "Li ha passat alguna cosa al Tomàs?” ('Has anything new happened to Tomàs?') vs. [NON-POLAR] “Què li passa al Tomàs últimament?” ('What is going on with Tomàs lately?')

Pol: "Déu meu! Està tan feliç des que té una xicota nova!” ('Oh my god! He is so happy since he has a new girlfriend!')

We collected judgments from 34 native Catalan and 61 native German speakers; Catalan speakers were tested within the context of a university class, and German speakers were recruited through Clickworker's crowdsourcing service (https://www. clickworker.de), following previous literature on experimentation in pragmatics (Degen et al., 2019). Participants had to rate the acceptability of Speaker B's reactions on a scale ranging from 1 (= very bad) to 6 (= very good). All Catalan participants passed a version of the Bilingual Linguistic Profile (Gertken et al., 2014), adapted to Catalonia's situation, where several degrees of Catalan-Spanish bilingualism coexist, and we discarded any candidate who was classified as a Spanish-dominant speaker (see Appendix C).

\subsection{Results}

Figs. 1 and 2 present the results for our filler items. Fillers for both languages were judged as expected, and the results of a one-way ANOVA of FILLER TYPE on acceptability judgments show that the main effect of FILLER TYPE on acceptability judgments was highly significant both for Catalan $(F(2,16)=798.15, p<.001)$ and for German $(F(2,55)=804.14, p<.001)$. We thus conclude that participants understood the task well and that they made use of the whole scale. 


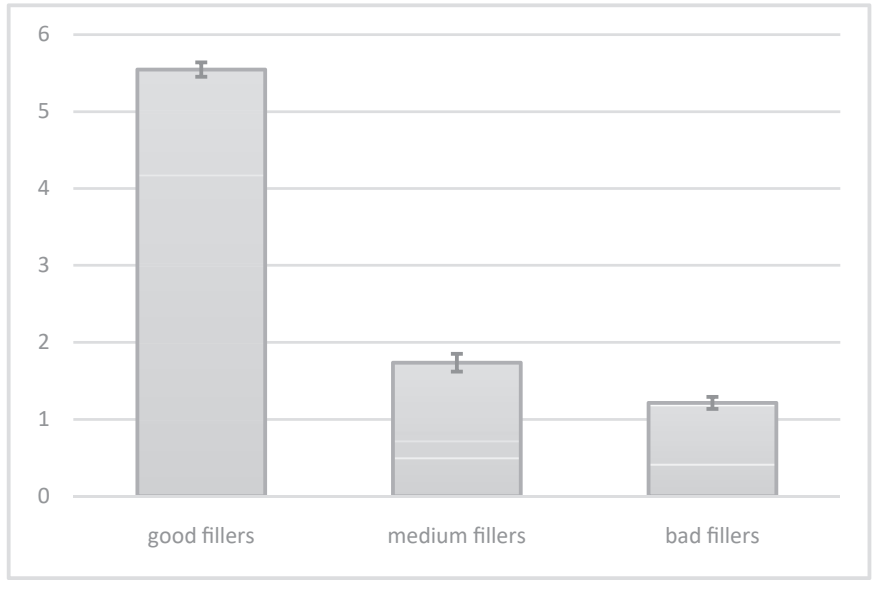

Fig. 1. Judgment of filler items (Catalan); whiskers represent SE.

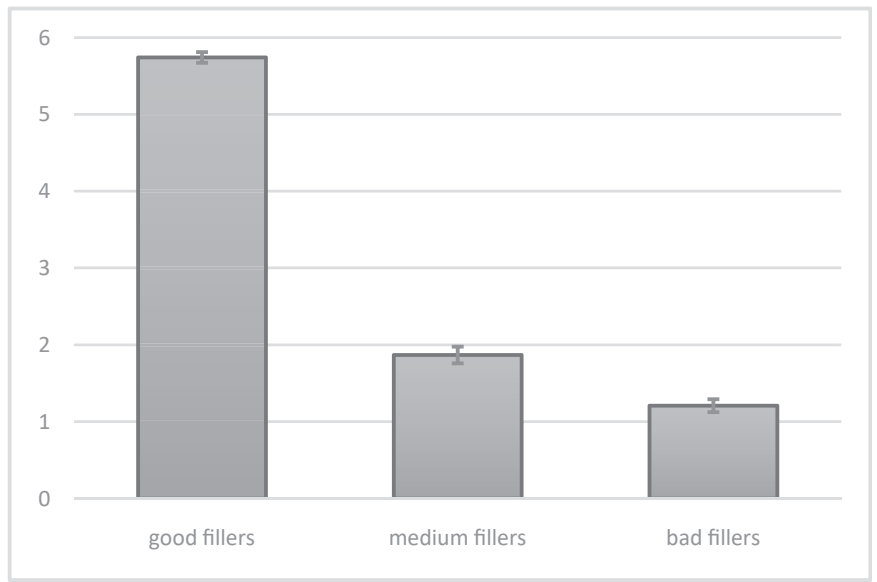

Fig. 2. Judgment of filler items (German); whiskers represent SE.

Let us now turn to the results for our critical items in both languages; Fig. 3 presents the results for the Catalan and Fig. 4 for the German items. For Catalan, a two-way ANOVA $(3 \times 2)$ revealed a significant main effect of EXCLAMATION FORM $(F(2$, $39)=9.32, p<.001)$ and a significant interaction of EXCLAMATION FORM and CONTEXT $(F(2,59)=9.43, p<.001)$, but we found no significant effect of CONTEXT $(F(1,27)=.92, p>.05)$.

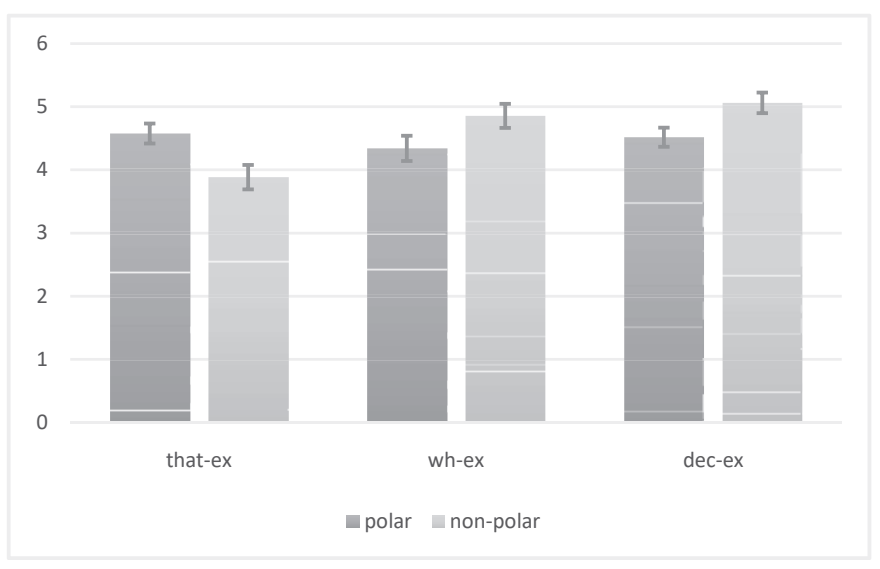

Fig. 3. Judgment of critical items (Catalan); whiskers represent SE. 


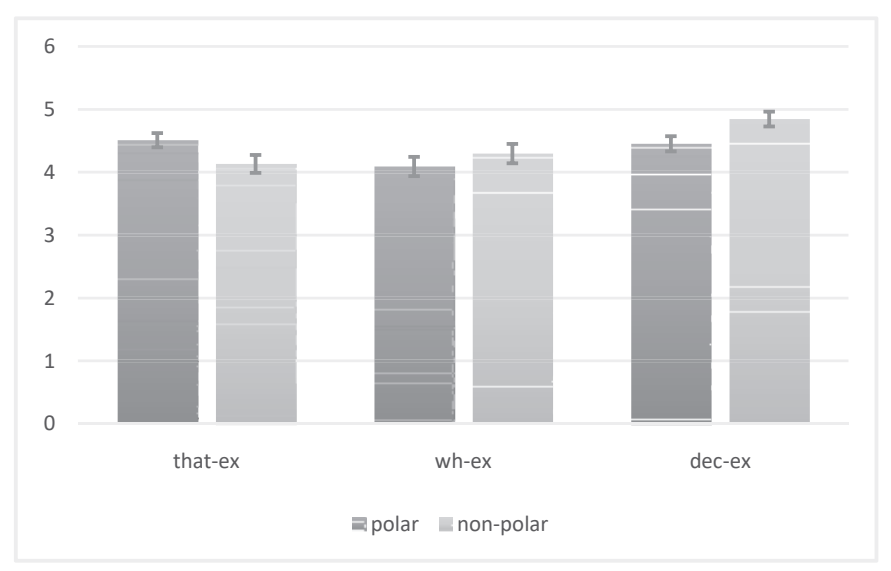

Fig. 4. Judgment of critical items (German); whiskers represent SE.

For German too, we found a highly significant main effect of EXCLAMATION FORM $(F(2,71)=11.43, p<.001)$ and a significant interaction of EXCLAMATION FORM and CONTEXT $(F(2,77)=7.70, p<.01)$. Again, there was no significant effect of conTEXT $(F(1$, $66)=.45, p>.05)$. Paired t-tests show that the difference between polar and non-polar contexts is significant within all exclamation-form conditions (in both languages), except for the German wh-exclamatives $(t(60)=-1.01, p>.05)$.

All in all, the experiment confirmed our initial expectations concerning the correlation between the kind of question and the kind of exclamative type: that-exclamatives in both languages were clearly preferred as responses to polar questions. Indeed, we obtained significant main effects for exclamation form $(p<.001)$, and a significant interaction between exclamation form and context $(p<.001)$. In the next section, we will now discuss these results in more detail and provide a theoretical account for these patterns.

\section{Exclamatives as responses and the syntax of answers}

It is clear from our experimental data in Section 2 that when used as a response to questions in a discourse, the acceptability of exclamatives depends on the form of the preceding question speech act: Polar questions can be followed by that-exclamatives, and non-polar questions can be followed by both wh-exclamatives and declarative exclamations. Our data indicate that this correlation is robust and holds beyond more than one language because similar results were obtained for Catalan and German. In this section, we propose that our data are relevant for discussing an empirical domain at the syntaxpragmatics interface that has been termed 'the syntax of answers' in more recent work (Holmberg, 2013, 2015; Haegeman and Weir, 2015; Wiltschko, 2018; Espinal and Tubau, 2019). In particular, in our experiment we observed distinctions across different syntactic forms (three ExcLAMATION FORMs) and not across different speech acts (all of them were exclamations). We will now illustrate to what extent our data contribute to recent work on the syntax of answers and add exclamatives as responses as an interesting topic to this type of literature at the syntax-pragmatics interface.

In the recent literature, we find a lot of ways of modeling the syntax of answers to questions. One of the most prominent accounts is Holmberg's $(2013,2015)$ theory about the syntax of 'yes' and 'no'. Since we are comparing discourses with polar and non-polar (wh-)questions, Holmberg's account is particularly appealing because it builds on the idea that the syntactic derivation of polar questions can be modeled in parallel to the derivation of $w h$-questions. His theory is built on the general framework of so-called 'cartographic' syntax, which represents discourse-related meaning like focus and topic in the left periphery of the clause (Rizzi, 1997, 2014). Since this model is controversial even among the proponents of generative syntax, let us briefly point out why we think that Holmberg's model-together with the advantages already pointed out above-is nevertheless a suitable account for explaining our empirical data.

The cartographic model of syntax is mainly criticized among formal syntacticians because both the model of grammar and the representational axioms of this approach to discourse meaning components are inconsistent with the more recent theoretical goal of minimizing representations in the syntactic component (e.g., Newmeyer, 2009; Trotzke and Zwart, 2014; see also Horvath's 2010 'Strong Modularity Hypothesis for Discourse Features' in this regard). It is important to note that these criticisms mainly concern the explanatory level(s) of syntactic theory (How can a language be acquired? How has language evolved?, etc.). However, the descriptive advantages of the cartographic framework have never been doubted, especially in cross-linguistic syntactic work. That is, approaching syntactic structures (and especially the clausal left periphery) from a cartographic perspective has proven to be incredibly fruitful. Since proponents of this approach are committed, by and large, to a rigorous methodology of description, they can rely on a large amount of previous work and thereby also refine our picture of the overall syntactic structure of heretofore under-researched languages (see Aboh, 2010; Ramchand and Svenonius, 2014; and many others on this point). Taken together with the advantage of Holmberg's $(2013,2015)$ theory that he offers a unified account for analyzing answers to polar and non-polar questions (which is exactly what we need), the cross-linguistic outlook of cartographic syntax is - to our mind-particularly suitable for our comparison of Catalan and German discourse syntax.

Given the conceptual background of cartographic syntax, Holmberg (2013) analyzes an answer-either affirmative (7a) or negative (7b) - to a polar question like Is he coming? as follows: 
(7) a. [FocP yes [Aff] [PolP he [Pol' is $+[$ Aff $][\mathrm{TP}<$ is $><$ he $>$ coming $]]]$

b. [FocP no [Neg] [PolP he [Pol' isn't $+[\mathrm{Neg}][\mathrm{TP}<\mathrm{is}><$ he $>$ coming $]]]$

The basic idea in (7) is that the answer particles 'yes' and 'no' are located in the specifier of a focus phrase (providing the 'new' information), and depending on their polarity (affirmative or negative), they assign their value (Aff or Neg) to a corresponding sentence-internal polarity feature (Pol), and this results in either an affirmative or negative assertion.

The representation of answer particles in a focus phrase is the key feature why Holmberg is able to model polar questions in parallel to wh-questions. In the case of a wh-question like Who is coming?, the answer term (e.g., Mary) is the focus constituent; accordingly, the answer term Mary assigns its focus value to a variable inside the propositional part of the utterance (on parallels and differences between wh-questions and other focus-marking constructions, see Truckenbrodt, 2013 and Eckardt, 2007):

(7') $[$ FocP Mary[Foc $][\mathrm{TP}<\mathrm{Mary}+[\mathrm{Foc}]>$ is coming $]]$

With this information-structural approach to the syntax of answers in mind, we are now in a position to explain our experimental data above. Let us consider first the case of wh-exclamatives. We observed that those exclamatives are preferred as responses in a discourse when they are preceded by wh-questions. Crucially, at first sight this goes against Grimshaw's (1979) classical observation that wh-exclamatives can never be used as responses to wh-questions. Here are her classical examples (Grimshaw, 1979: 321):

(8) A: How tall is John?

B: \# How tall John is!

B': John is very tall.

While we agree with her basic observation, we submit that Grimshaw's example (8B) is bad not because it involves an exclamative per se, but because it features an information-structural mismatch. Note that her example contains a narrow focus ('how tall'), and the response in (8B) is intended as a direct answer to this narrow-focus question. In contrast, in our experiment we used wh-questions where the focus is broader (e.g., How is Marc doing?, How was the race for Stefan?...; see Appendix A), ${ }^{3}$ and thus the respective answers inferred from the exclamative responses do not necessarily have to be narrow (e.g., Marc is doing good, The race was good for Stefan,...). In other words, the broad-focus questions in our cases enable the responses to be more indirect, and this is why exclamatives in those broad contexts can indeed be used as responses to a question, contra Grimshaw's (1979) general claim. ${ }^{4}$ The indirect way of providing a direct answer by means of an exclamative response can be illustrated as follows:

(9) a. broad-focus question: How was the race for Stefan?

b. Wie schnell er wieder war! [German exclamative]

Que ràpid que ha tornat a ser! [Catalan exclamative]

'How fast he was again!'

c. 'Stefan was again extremely fast.' [descriptive content conveyed by (9b)]

\footnotetext{
${ }^{3}$ In what follows, we also give English versions and/or translations of the materials used in our experiment to improve the readability of our paper. Crucially, this will also concern the different exclamative types. While there is no problem with giving the English counterparts for the Catalan/German wh-exclamatives, we would like to clarify at this point that our translations of that-exclamatives (e.g., 'That he is beautiful!') do not imply that configurations like this can be used in English.

${ }^{4}$ Let us point out here that we did not design the items for that-exclamatives according to information-structural considerations like that. The reason for this is that we thought that while it is possible to control for 'polar vs. non-polar' discourses across exclamative types and the two languages Catalan and German, it might be harder to test felicity patterns in the context of 'narrow vs. broad focus' across the two languages. To see this, please note that thatexclamatives in German can feature a degree predicate like in our experimental item (i), but they can also lack such a predicate like in our item (ii):
}

(i) Marc: „Ach der Hans! Dass ich ihn so lange nicht gesehen habe!“

Marc: "Lordy, Hans! How long it has been since I have last seen him!"

(ii) Vater: „Ach herrje! Dass ich die vergessen habe!“”

Father: "Yikes! How could I have forgotten this one!" 
In (9), we see that an exclamative (9b) conveys a descriptive content (9c) from which the answer for the broad-focus question (9a) can be inferred (i.e., 'if he was again fast, then the race went very well for Stefan'). Accordingly, the matching of the descriptive content of the exclamative (9c) and the broad-focus question (9a) is a pragmatic one (i.e., the answer can be inferred).

The puzzle about our data now is that the same broad-focus wh-questions cannot be responded to by the syntactic form of a that-exclamative. This is unexpected because our experimental items of that-exclamatives (e.g., 'That he was so strongminded again!') express a similar descriptive content ('He was so strong-minded again'), which in principle could also serve as an indirect answer to broad-focus wh-questions. However, this is not what we found in our experiment. The syntactic form of that-exclamatives is only acceptable when preceded by polar questions. We thus conclude that there has to be a difference in the syntax (i.e., the syntactic form) of answers.

Given what we have introduced about the syntax of answers above (7)/(7'), we can analyze this difference by extending Holmberg's account to our exclamative data. In particular, we postulate that while the wh-element in wh-exclamatives binds a (degree/d) variable inside the proposition (10), the complementizer that in that-exclamatives assigns a value to a corresponding sentence-internal polarity feature (11); the interpretation of the descriptive contents of both exclamative forms as responses to the questions in (10) and (11) is a matter of pragmatic inferencing, as discussed above (9). In particular, the relevant answer proposition can be inferred from the literal utterances in both (10) and (11), and it receives an extra value (either negative or affirmative) when combined with the polarity-bearing complementizer 'that' (11):

(10) broad wh-question: How was the race for Stefan?

The race was good.

PRAGMATIC INFERENCING (inferred p)

wh-excl: $\quad\left[\right.$ FocP $[\text { how fast }]_{[\mathrm{Foc}]}[\mathrm{TP}$ he was $<d$ fast $+[$ Foc $]>$ again $\left.]\right]$

'+> inferred proposition: The race was good.'

(11) polar question: Did your friend achieve his goal again?

Yes (he has achieved his goal again).

॥PRAGMATIC INFERENCING $(\{$ Aff, Neg $\}+$ inferred $\mathbf{p})$

that-excl ('That he was so strong-minded again!'):

[FocP dass $[\{$ Aff, Neg $\}]\left[\right.$ PolP er $\left[\right.$ Pol ${ }^{\prime}<$ war $+[\{$ Aff, Neg $\}]>[$ тр $<$ er $><$ war $>$ erneut so willensstark $\left.\left.\left.]\right]\right]\right]$

'+> inferred proposition: He has achieved

his goal again'

$[$ FocP que $[\{$ Aff, Neg $\}][$ PolP $\varnothing[$ Pol' $<$ n'ha $+[\{$ Aff, Neg $\}]>[$ тр $<$ n'ha $>$ a ser de resistent $]]]]$

'+> inferred proposition: He has achieved

his goal again'

Our theoretical proposal is based on the following empirical observations: First, it is pointed out, at least since Grimshaw (1979), that wh-exclamatives convey the same descriptive content as declarative assertions involving a degree variable. In particular, How fast he was! is interpreted at the descriptive level as a statement such as He was extremely fast, an end-ofscale degree. Note that How fast he was! and He was extremely fast of course differ in either conveying that the fact that someone was extremely fast obligatorily violates the speaker's expectation (wh-exclamative) or expressing that this fact must not necessarily violate that expectation (declarative assertion). However, the descriptive content featuring a degree 
interpretation is the same for both utterance types: They both convey that a property (here: 'being fast') holds to an extreme degree. The only difference is that wh-exclamatives lack an apparent degree modifier like extremely, and that the end-of-scale degree reading is always part of the descriptive content of their syntactic form (see Beltrama and Trotzke, 2019 for even more lexical and syntactic strategies to yield such a degree reading). All in all, this is why in (10) we postulate that the combination [how fast] expresses a degree reading ('extremely fast') and that this degree reading must be part of the propositional content of the utterance, which, according to the syntactic approach we are adopting here, is represented inside the sentence-level phrase ' $\mathrm{T}(\mathrm{ense}) \mathrm{P}$ (hrase)'. The result is that items like [how fast] in exclamatives bind a degree variable inside the proposition.

Let us now turn to the second representation in (11) and its empirical and theoretical rationale in connection to what we are claiming in (10). At the outset of this section, we already made clear that one particularly appealing component of Holmberg's $(2013,2015)$ theory about the syntax of answers is that he deals with different types of answers from an information-structural and thus from a discourse perspective. More specifically, response particles like yes and no are analyzed as providing the information focus of a discourse because they contain the 'new' information for the hearer. Accordingly, those particles can occupy the syntactic position of a 'focus phrase' (FocP) just as other focus elements can (like wh-elements in wh-questions or focal phrases in declarative assertions). Crucially, however, the 'information focus' in the case of yes and no is polar: either the new information is that something is the case or the new component of the utterance is that something is not the case. This differs from other cases of information focus where more than two alternatives (a non-polar choice) can be the basis for providing the relevant new information (e.g., Who is coming? \{Mary, John, Peter...\} is coming).

Now, it is clear that both our wh-exclamatives and our that-exclamatives are not direct responses like yes, no, or Mary is coming, but rather allow for pragmatic inferences that provide the relevant responses given in (10) and (11) above. However, our data in Section 2 show that they do so in very different ways: While wh-exclamatives can provide new information from which a non-polar answer to a non-polar question can be inferred (10), wh-exclamatives cannot convey information from which a polar answer ('yes' or 'no') to a polar question can be inferred (as our experimental data show). The opposite holds for that-exclamatives: They can only be used as providing answers to polar questions, and they are pragmatically odd in a context where more than two choices-Aff(irmative) or Neg(ative)-are part of the discourse (see experimental data in Section 2). Since the only difference between the two exclamative forms is a syntactic one (either the left periphery contains the complementizer that or a wh-phrase), we submit that those different discourse constraints have to be encoded in their syntax along the lines of Holmberg's syntax of answers; this approach precisely distinguishes between syntactic forms that are felicitous in polar contexts (binding an Aff or Neg feature inside the proposition) and syntactic forms that are tied to non-polar contexts (binding a non-polar focus inside the proposition).

Accordingly, our new observation is that the complementizer that-when used in a that-exclamative-can assign a polarity feature, either affirmative as in (11) or negative as in Do you have the phone number? 'That I am so forgetful!' (=> No); see Appendix A for such an example. Consequently, in contrast to the polarity operators 'yes' or 'no', the complementizer that acts as a polarity anaphor that has to obtain its value from the discourse context. ${ }^{5}$ This analysis also explains why whexclamatives pattern with declarative exclamations: Declarative exclamations do not involve assignment of a polarity feature, but rather they involve binding of a focus variable inside the proposition. Note that in our items, the focus is expressed in situ (e.g., He was so fast again!); see the following example and Appendix A:

(12) broad wh-question: How was the race for Stefan?

The race was good.

|| PRAGMATIC INFERENCING

decl-excl: $\quad[$ FocP $[$ Foc $][$ Tтр he was $<$ so fast $+[$ Foc $]>$ again $]]$

Like wh-exclamatives (10), declarative exclamations are bad in polar contexts because their syntax (lacking a polarity anaphor and sentence-internal polarity) does not license this particular information-structural setting.

\footnotetext{
${ }^{5}$ As one anonymous reviewer notes, this analysis of the complementizer 'that' is further corroborated by the fact that the Catalan complementizer que can introduce polar questions (see Prieto and Rigau, 2007; Corr, 2018; and Feldhausen and Villalba, 2020):
}

(i)
Que vindràs?
that come.FUT.2SG
'Are you coming?' 
All in all, our analysis of the experimental data in Section 2 highlights the fact that the differences between the response uses of wh-exclamatives and that-exclamatives should be explained on syntactic grounds, because it clearly is the different form of the two exclamative strategies that results in their different pragmatic felicity. As a consequence, we have demonstrated that the way exclamatives have been viewed from a discourse perspective must be broadened: First, it is simply not true that exclamatives are infelicitous as responses, as has been claimed in many of the seminal papers on exclamatives (e.g., Grimshaw, 1979; Zanuttini and Portner, 2003). Second, we can even observe interesting new distinctions at the syntaxpragmatics interface when looking at the response uses of exclamatives. In the last section of the paper, we will now summarize our findings and point out some implications that go beyond the empirical domain of exclamatives.

\section{Conclusions}

In this paper, we have capitalized on the fact that exclamatives can be used as responses, and in this use they provide propositional content from which the direct answer to the relevant question can be inferred. Note that this indirect way of answering a question is actually a widespread strategy. For instance, one could also answer a question by means of a presupposition like in the following case:

(13) Context: A group of friends just finished dinner, and suddenly one of them realizes that Mary

is missing at the table and went to the balcony.
A: What is Mary doing on the balcony?
B: She hasn't managed to quit smoking.

In (13), the proposition 'Mary smokes' is derived from the presuppositional trigger hasn't managed, which allows the hearer to generate the conversational implicature that 'Mary is smoking on the balcony', which serves as a felicitous answer to the question posed by A. Obviously, (13B) is a marked and an indirect way to give an answer; however, it technically works just as typical cases of relevance implicatures already discussed in seminal work by Grice $(1975,1981)$ and recently investigated by Walker et al. (2011) and de Marneffe and Tonhauser (2019). In particular, the content of the answer is inferred from the 'at-issue' meaning of the utterance ('Mary smokes' in (13B)) by means of general conversational principles: Since the utterance in (13B) violates the so-called 'maxim of relevance' (i.e., it is not immediately relevant to Speaker A's wh-question), it is not in accordance with the more general cooperative principle: "I expect a partner's contribution to be appropriate to immediate needs at each stage of the transaction." (Grice, 1975: 47) In the concrete case of (13), this violation results in the implicature 'She hasn't managed to quit smoking. +> Mary is smoking on the balcony.'

According to a strictly pragmatic perspective, the respective syntactic forms of indirect responses that are based on such pragmatic inferencing should not really be relevant to the felicity of the response. Consequently, the only thing that should matter is the propositional content of the response (giving rise to the relevant implicatures) and not the syntactic format it appears in. However, given our data in this paper, one can question such a purely pragmatic approach.

In particuolar we have shown that different syntactic forms of exclamatives must match the information structure of the preceding questions, and crucially this seems to hold cross-linguistically. More specifically, our new claim is that the complementizer that - when used in a that-exclamative in Catalan and German-can assign a polarity feature, and this results in its restriction to polar-question contexts. On the other hand, wh-exclamatives (and declarative exclamations for that matter) do not obligatory feature such a polarity assignment. That is, they are felicitous in both polar and non-polar contexts in German, and even infelicitous in polar contexts in Catalan. The main finding of our study is thus that only that-exclamatives in both languages are clearly preferred as responses to polar questions, and we therefore conclude that the role of exclamatives in discourse cannot be explained by pragmatic means only, but is also restricted by features at the interface of pragmatics with syntactic form. Crucially, we have demonstrated that some features at this interface seem to hold cross-linguistically (in our case for a Germanic and a Romance language). At a more general level, we hope that our inclusion of exclamatives as responses in the syntax of answers has added a new empirical domain to recent work in this domain at the syntax-pragmatics interface and will inspire drawing further empirical distinctions in investigations that look into how different syntactic forms can be used in a dialogue.

\section{Acknowledgements}

We thank the audience at the DGfS 2019 conference (U Bremen) and at the workshop on "Functional categories and expressive meaning" (UAB, Barcelona/2019) for extremely helpful comments and discussion. Andreas Trotzke gratefully acknowledges financial support from the Beatriu de Pinós program (Generalitat de Catalunya/Secretariat for Universities and Research of the Ministry of Economy and Knowledge; grant no. 2017-BP00031). Andreas Trotzke and Xavier Villalba were furthermore supported by the grants FFI2017-82547-P (MINECO) and 2017SGR634 (AGAUR), awarded to UAB's Center for Theoretical Linguistics. 
Appendix

(A)

\section{Catalan critical items (incl. translations)}

THAT-EXCLAMATIVES - POLAR CONTEXT

(1) La Júlia parla amb el Marc sobre alguns vells amics de l'escola.

Julia is talking to Marc about some old friends from their school days.

Júlia: "Saps alguna cosa del Joan?"

Julia: "Have you heard from Joan recently?"

Marc: "El Joan, redeu! Que en fa de temps que no el veig!"

Marc: "Lordy, Joan! How long it has been since I have last seen him!"

(2) Els pares poleixen els últims detalls de l'aniversari de la seva filla.

The parents make the last arrangements for their daughter's birthday.

Mare: "Tens el telèfon del pastisser que ha de fer el pastís?"

Mother: "Do you have the phone number of the bakery which is going to bake the cake?"

Pare: "Quin greu! Que en sóc de despitat!"

Father: "Yikes! How forgetful I am!"

(3) El professor parla amb el seu ajudant d'un alumne que havia de repetir l'examen.

The professor is talking to his assistant about a student who had to redo the exam.

Professor: "Ha aprovat, aquesta vegada?"

Professor: "Did he pass the exam this time?"

Ajudant: “És increïble! Que n'ha arribat a fer-lo de malament!”

"How poorly he has performed again!"

(4) Verena parla amb la seva mare del seu pare, que vol acabar la seva segona marató.

Verena is talking to her mum about her dad, who wanted to finish a marathon for the second time.

Verena: "Ho ha tornat a fer?"

Verena: "Did he achieve his goal again?"

Mare: "No te'n sabràs avenir! Que n'ha tornat a ser de resistent!"

Mother: "You won’t believe it! How strong-minded he was again!" 
(1) L'Eva ha quedat amb la Laura i es pregunta si encara li va tan bé la feina al marit de la Laura.

Eva is meeting Laura and wonders if Laura's husband Markus is still so successful.

Eva: "I doncs, li va bé al Marc?"

Eva: "So, is Marc doing well?"

Laura: "Oh! Quants encàrrecs que té sempre!"

Laura: "Oh! How many appointments he always has!"

(2) En Josep i la Maria es pregunten si el seu germà Carles encara viu sol.

Josep is wondering together with Maria if his brother Carles still lives all alone.

Josep: “Té una nova parella?"

Josep "Did he find a new girlfriend?"

Maria: "No te'n sabràs avenir! Que feliç que torna a ser!"

Maria: "You won't believe it! How happy he is again!"

(3) L'Esteve. el millor amic del Sebastià, ha participat amb la Lisa en una cursa ciclista.

Sebastià's best friend Stefan participated in a cycling race together with Lisa.

Sebastià: "Ha tingut èxit a la cursa, l'Esteve?"

Sebastià: "Has the race been a success for Stefan?"

Lisa: "Increïble! Que ràpid que ha tornat a ser!"

Lisa: "Unbelievable! How fast he was again!"

(4) En Carles té un nou cap a la feina i parla amb un dels seus companys.

Carles has a new boss at work and is talking to one of his colleagues.

Company: "T'ha fet bona impressió el nou cap?"

Colleague: "Does your new boss make a good impression?"

Carles: "Déu meu! Que mesquí que és aquest paio!"

Carl: "My God! How mean this guy is!" 
(1) El Jordi s'ha adonat que el Tomàs, l'amic del Pol, està canviat. Jordi noticed that Pol's friend Tomàs has somehow changed. Jordi: "Li ha passat alguna cosa al Tomàs?" Jordi: "Has anything new happened to Tomàs?"

Pol: "Déu meu! Està tan feliç des que té una xicota nova!"

Pol: "My God! He is so happy since he has a new girlfriend!

(2) Laura és de vacances i parla per telèfon amb la seva germana.

Brigitte is on vacation right now and is on the phone with her sister.

Germana: "Fa bon temps a Grècia?"

Sister: "Is the weather nice in Greece?"

Laura: "No t'ho creuràs! La gent es passa el dia asseguda a les terrasses!"

Laura: "Guess what! The people here sit outside the whole day!"

(3) El Ferran ha sentit que la Cristina té un nou company de pis.

Ferran has heard that Cristina has a new roommate.

Ferran: "És agradable el teu nou company de pis?"

Ferran: "Is he a pleasant roommate?"

Cristina: “Oh, Déu meu! És tan desendreçat!”

Cristina: "Oh my God! He is so messy!"

(4) Caterina consulta el mapa per trobar-li a la seva mare el nou barri del Max.

Caterina looks at the map for her mother to find the new neighborhood of Max.

Mare: "Ha triat un bon barri?"

Mother: "Did he choose a nice neighborhood?"

Caterina: "Quin greu! Ës tan lluny!"

Caterina: "Yikes! It is so far away!" 
(1) La Júlia parla amb el Marc sobre alguns vells amics de l'escola.

Júlia is talking to Marc about some old friends from their school days.

Júlia: "Quan vas saber alguna cosa del Joan?"

Júlia: "When have you heard something from Joan last time?"

Marc: "El Joan, redeu! Que en fa de temps que no el veig!"

Marc: "Lordy, Joan! How long it has been since I have last seen him!"

(2) Els pares poleixen els últims detalls de l'aniversari de la seva filla.

The parents make the last arrangements for their daughter's birthday.

Mare: "Quin és el telèfon del pastisser que ha de fer el pastís?"

Mother: "Which one is the phone number of the bakery which is going to bake the cake?"

Pare: "Quin greu! Que en sóc de despitat!"

Father: "Yikes! How could I have forgotten this one!"

(3) El professor parla amb el seu ajudant d'un alumne que havia de repetir l'examen.

The professor is talking to his assistant about a student who had to redo the exam.

Professor: "Quina nota ha tret aquesta vegada?"

Professor: "Which result has he achieved this time?"

Ajudant: “És increïble! Que n'ha arribat a fer-lo de malament!"

"How poorly he has performed again!"

(4) La Verònica parla amb la seva mare del seu pare, que vol acabar la seva segona marató.

Verònica is talking to her mum about her dad, who wanted to finish a marathon for the second time.

Verònica: "Quin resultat ha obtingut en aquest segon intent?"

Verònica: "What was the result of his second attempt?"

Mare: "No te'n sabràs avenir! Que n'ha tornat a ser de resistent!"

Mother: "You won't believe it! How strong-minded he was again!"

WH-EXCLAMATIVES - NON-POLAR CONTEXT

(1) L'Eva ha quedat amb la Laura i es pregunta si encara li va tan bé la feina al marit de la Laura, el Marc.

Eva is meeting Laura and wonders if Laura's husband Marc is still so successful.

Eva: "Com va de feina, el Marc?"

Eva: "So, how is Marc doing?"

Laura: "Oh! Quants encàrrecs que sempre té!"

Laura: "Oh! How many appointments he always has!" 
(2) En Josep i la Maria es pregunten si el seu germà Carles encara viu sol.

Josep is wondering together with Maria if his brother Carles still lives all alone.

Josep: “Com li va la recerca d'una nova parella?"

Josep "How is his search for a new girlfriend going?"

Maria: "No te'n sabràs avenir! Que feliç que torna a ser!"

Maria: "You won't believe it! How happy he is again!"

(3) L'Esteve. el millor amic del Sebastià, ha participat amb la Lisa en una cursa ciclista.

Sebastià's best friend Stefan participated in a cycling race together with Lisa.

Sebastià: "Com li ha anat la cursa, a l'Esteve?"

Sebastià: "How was the race for Stefan?"

Lisa: "Increïble! Que ràpid que ha tornat a ser!"

Lisa: "Unbelievable! How fast he was again!"

(4) El Carles té un nou cap a la feina i parla amb un dels seus companys.

Carles has a new boss at work and is talking to one of his colleagues.

Company: "Quina impressió t'ha fet, el nou cap?"

Colleague: "What kind of impression does your new boss make?"

Carles: "Déu meu! Que mesquí que és aquest paio!"

Carl: "My God! How mean this guy is!"

DECLARATIVE - NON-POLAR CONTEXT

(1) El Jordi s'ha adonat que el Tomàs, l'amic del Pol, està canviat.

Jordi noticed that Pol's friend Tomàs has somehow changed.

Jordi: “Què li passa al Tomàs ultimament?"

Jordi: "What is going on with Tomàs recently?"

Pol: "Déu meu! Està tan feliç des que té una xicota nova!"

Pol: "My God! He is so happy since he has a new girlfriend!" 
(2) La Laura és de vacances i parla per telèfon amb la seva germana.

Laura is on vacation right now and is on the phone with her sister.

Germana: "Com és el temps a Grècia?"

Sister: "How is the weather in Greece?"

Laura: "No t'ho creuràs! La gent es passa el dia asseguda a les terrasses!"

Laura: "Guess what! The people here sit outside the whole day!"

(3) El Ferran ha sentit que la Cristina té un nou company de pis.

Ferran has heard that Cristina has a new roommate.

Ferran: "Com és el teu nou company de pis?"

Ferran: "How is your new roommate?"

Cristina: “Oh, Déu meu! És tan desendreçat!”

Cristina: "Oh my God! He is so messy!"

(4) Caterina consulta el mapa per trobar-li a la seva mare el nou barri del Max.

Csterina looks at the map for her mother to find the new neighborhood of Max.

Mare: "Què et sembla el barri que ha triat?"

Mother: "What are you thinking about his choice of neighborhood?"

Caterina: "Quin greu! Ës tan lluny!"

Caterina: "Yikes! It is so far away!" 


\section{German critical items (incl. translations)}

THAT-EXCLAMATIVES - POLAR CONTEXT

(1) Julia spricht mit Marc über alte Freunde aus der Schulzeit.

Julia is talking to Marc about some old friends from their school days.

Julia: „Hast Du in letzter Zeit mal von Hans gehört?“

Julia: "Have you heard from Hans recently?"

Marc: „Ach der Hans! Dass ich ihn so lange nicht gesehen habe!“

Marc: "Lordy, Hans! How long it has been since I have last seen him!"

(2) Die Eltern treffen die letzten Vorbereitungen für den Geburtstag ihrer Tochter.

The parents make the last arrangements for their daughter's birthday.

Mutter: „Hast Du die Telefonnummer vom Bäcker, der den Kuchen backen soll?“

Mother: "Do you have the phone number of the bakery which is going to bake the cake?"

Vater: „Ach herrje! Dass ich die vergessen habe!“

Father: "Yikes! How could I have forgotten this one!"

(3) Der Professor unterhält sich mit seinem Mitarbeiter über einen Studenten, der die Prüfung wiederholen musste.

The professor is talking to his assistant about a student who had to redo the exam.

Professor: „Hat er die Prüfung denn diesmal bestanden?““

Professor: "Did he pass the exam this time?"

Mitarbeiter: „Es ist unglaublich! Dass er das schon wieder nicht geschafft hat!“

Assistant: "It's unbelievable! How could he have not passed it again!"

(4) Verena spricht mit ihrer Mutter über ihren Vater, der zum zweiten Mal einen Marathon beenden wollte.

Verena is talking to her mum about her dad, who wanted to finish a marathon for the second time.

Verena: „Hat er denn wieder sein Ziel erreicht?“

Verena: "Did he achieve his goal again?"

Mutter: „Du glaubst es nicht! Dass er erneut so willensstark war!““

WH-EXCLAMATIVES - POLAR CONTEXT

(1) Eva trifft Laura und fragt sich, ob Lauras Mann Markus immer noch so erfolgreich ist.

Eva is meeting Laura and wonders if Laura's husband Markus is still so successful.

Eva: „Geht es Markus denn gut?“

Eva: "So, is Markus doing well?"

Laura: „Oh! Wie viele Termine der immer hat!“

Laura: "Oh! How many appointments he always has!" 
(2) Josef fragt sich zusammen mit Maria, ob sein Bruder Olaf immer noch ganz alleine lebt.

Josef is wondering together with Maria if his brother Olaf still lives all alone.

Josef: „Hat er eine neue Freundin gefunden?“

Josef: "Did he find a new girlfriend?"

Maria: „Du wirst es nicht glauben! Wie glücklich er nun wieder ist!“

Maria: "You won't believe it! How happy he is again!"

(3) Sebastians bester Freund Stefan hat zusammen mit Lisa an einem Radrennen teilgenommen.

Sebastian's best friend Stefan participated in a cycling race together with Lisa.

Sebastian: „Ist das Rennen für Stefan erfolgreich verlaufen?““

Sebastian: "Has the race been a success for Stefan?"

Lisa: „Unglaublich! Wie schnell er wieder war!“

Lisa: "Unbelievable! How fast he was again!"

(4) Karl hat einen neuen Boss auf der Arbeit und unterhält sich mit einem seiner Kollegen.

Karl has a new boss at work and is talking to one of his colleagues.

Kollege: „Macht Dein neuer Boss einen guten Eindruck?“

Colleague: "Does your new boss make a good impression?"

Karl: „Mein Gott! Wie gemein dieser Kerl ist!

Karl: "Oh my God! How mean this guy is!"

\section{DECLARATIVE - POLAR CONTEXT}

(1) Fabian ist aufgefallen, dass sich Ulis Freund Thomas irgendwie verändert hat.

Fabian noticed that Uli's friend Thomas has somehow changed.

Fabian: „Ist mit Thomas irgendetwas Neues passiert?“

Fabian: "Has anything new happened to Thomas?"

Uli: „Mein Gott! Er ist so glücklich, seit er eine neue Freundin hat!““

Uli: "Oh my god! He is so happy since he has a new girlfriend!" 
(2) Brigitte ist gerade im Urlaub und telefoniert mit ihrer Schwester.

Brigitte is on vacation right now and is on the phone with her sister.

Schwester: „Ist es schönes Wetter in Spanien?“

Sister: "Is the weather nice in Spain?"

Brigitte: „Stell Dir vor! Die Leute sitzen den ganzen Tag draußen!“

Brigitte: "Guess what! The people here sit outside the whole day!"

(3) Fabian hat gehört, dass Kristina einen neuen Mitbewohner hat.

Fabian has heard that Katharina has a new roommate.

Fabian: „Ist er ein angenehmer Mitbewohner?“

Fabian: "Is he a pleasant roommate?"

Kristina: „Oh mein Gott! Er ist so unordentlich!“

Kristina: "Oh my God! He is so messy!"

(4) Katharina schaut auf die Karte, um für ihre Mutter den neuen Wohnort von Max zu finden.

Katharina looks at the map for her mother to find the new neighborhood of Max.

Mutter: „Hat er sich denn eine schöne Gegend ausgesucht?“

Mother: "Did he choose a nice neighborhood?"

Katharina: „Ach herrje! Das ist so weit weg!“

Katharina: "Yikes! It is so far away!"

\section{THAT-EXCLAMATIVES — NON-POLAR CONTEXT}

(1) Julia spricht mit Marc über alte Freunde aus der Schulzeit.

Julia is talking to Marc about some old friends from their school days.

Julia: „Wann hast Du eigentlich das letzte Mal etwas von Hans gehört?““

Julia: "When have you heard something from Hans last time?"

Marc: „Ach der Hans! Dass ich ihn so lange nicht gesehen habe!“‘

Marc: "Lordy, Hans! How long it has been since I have last seen him!" 
(2) Die Eltern treffen die letzten Vorbereitungen für den Geburtstag ihrer Tochter.

The parents make the last arrangements for their daughter's birthday.

Mutter: „Welches ist die Telefonnummer vom Bäcker, der den Kuchen backen soll?““

Mother: "Which one is the phone number of the bakery which is going to bake the cake?"

Vater: „Ach herrje! Dass ich die vergessen habe!“

Father: "Yikes! How could I have forgotten this one!"

(3) Der Professor unterhält sich mit seinem Mitarbeiter über einen Studenten, der die Prüfung wiederholen musste.

The professor is talking to his assistant about a student who had to redo the exam.

Professor: „Welches Resultat hat er denn diesmal erreicht?““

Professor: "Which result has he achieved this time?"

Mitarbeiter: „Es ist unglaublich! Dass er das schon wieder nicht geschafft hat!“

Assistant: "It's unbelievable! How could he have not passed it again!"

(4) Verena spricht mit ihrer Mutter über ihren Vater, der zum zweiten Mal einen Marathon beenden wollte.

Verena is talking to her mum about her dad, who wanted to finish a marathon for the second time.

Verena: „Was war das Resultat seines zweiten Versuchs?“

Verena: "What was the result of his second attempt?"

Mutter: „Du glaubst es nicht! Dass er erneut so willensstark war!“

Mother: "You won't believe it! How strong-minded he was again!"

\section{WH-EXCLAMATIVES - NON-POLAR CONTEXT}

(1) Eva trifft Laura und fragt sich, ob Lauras Mann Markus immer noch so erfolgreich ist.

Eva is meeting Laura and wonders if Laura's husband Markus is still so successful.

Eva: „Wie geht es eigentlich Markus?“

Eva: "So, how is Markus doing?"

Laura: „Oh! Wie viele Termine der immer hat!““

Laura: "Oh! How many appointments he always has!" 
(2) Josef fragt sich zusammen mit Maria, ob sein Bruder Olaf immer noch ganz alleine lebt.

Josef is wondering together with Maria if his brother Olaf still lives all alone.

Josef: „Wie läuft seine Suche nach einer neuen Freundin?“

Josef: "How is his search for a new girlfriend going?"

Maria: „Du wirst es nicht glauben! Wie glücklich er nun wieder ist!“

Maria: "You won't believe it! How happy he is again!"

(3) Sebastians bester Freund Stefan hat zusammen mit Lisa an einem Radrennen teilgenommen.

Sebastian's best friend Stefan participated in a cycling race together with Lisa.

Sebastian: „Wie war das Rennen für Stefan?“

Sebastian: "How was the race for Stefan?"

Lisa: „Unglaublich! Wie schnell er wieder war!“

Lisa: "Unbelievable! How fast he was again!"

(4) Karl hat einen neuen Boss auf der Arbeit und unterhält sich mit einem seiner Kollegen.

Karl has a new boss at work and is talking to one of his colleagues.

Kollege: „Was für einen Eindruck macht Dein neuer Boss?“

Colleague: "What kind of impression does your new boss make?"

Karl: „Mein Gott! Wie gemein dieser Kerl ist!

Karl: "My God! How mean this guy is!"

DECLARATIVE - NON-POLAR CONTEXT

(1) Fabian ist aufgefallen, dass sich Ulis Freund Thomas irgendwie verändert hat.

Fabian noticed that Uli's friend Thomas has somehow changed.

Fabian: „Was ist mit Thomas denn los in letzter Zeit?“

Fabian: "What is going on with Thomas recently?"

Uli: „Mein Gott! Er ist so glücklich, seit er eine neue Freundin hat!““

Uli: "My god! He is so happy since he has a new girlfriend!" 
(2) Brigitte ist gerade im Urlaub und telefoniert mit ihrer Schwester.

Brigitte is on vacation right now and is on the phone with her sister.

Schwester: „Wie ist das Wetter in Spanien?“

Sister: "How is the weather in Spain?"

Brigitte: „Stell Dir vor! Die Leute sitzen den ganzen Tag draußen!“

Brigitte: "Guess what! The people here sit outside the whole day!"

(3) Fabian hat gehört, dass Kristina einen neuen Mitbewohner hat.

Fabian has heard that Katharina has a new roommate.

Fabian: „Wie ist Dein neuer Mitbewohner?““

Fabian: "How is your new roommate?"

Kristina: „Oh mein Gott! Er ist so unordentlich!“

Kristina: "Oh my God! He is so messy!"

(4) Katharina schaut auf die Karte, um für ihre Mutter den neuen Wohnort von Max zu finden.

Katharina looks at the map for her mother to find the new neighborhood of Max.

Mutter: „Was denkst Du über seine Wohnungswahl?““

Mother: "What are you thinking about his choice of neighborhood?"

Katharina: „Ach herrje! Das ist so weit weg!“

Katharina: "Yikes! It is so far away!"

(B)

\section{Catalan filler items (incl. translations)}

\section{GOOD}

(1) En Quim i la Mònica parlen de la seva amiga, la Linda.

Quim and Monica are talking about their friend Linda.

Quim: "La Linda té un fill espavilat."

Quim: "Linda has a smart son."

Mònica: "No, això no és així."

Mònica: "No, that's not right." 
(2) La mare i la filla parlen de les fenes de l'endemà.

Mother and daughter discuss the plan for tomorrow.

Filla: "Haig de netejar la meva habitació?"

Daughter: "Do I really have to clean up my room?"

Mare: "Sí”"

Mother: Yes.

(3) La mestra parla amb una col·lega seva sobre la Clàudia, una estudiant seva.

The teacher is talking to her colleague about their student Claudia.

Mestra: "La Claudia ha fet un gran treball."

Teacher: "Claudia has written a great essay."

\section{Col·lega: "Sí, jo també ho penso."}

Colleague: "Yes, I agree."

(4) La Irene s'adona que al carrer fa molt de vent i s'amoïna pel seu marit, Claudi. Irene notices that it is very windy outside and worries about her husband Claudi. Irene: "Serà millor que t'enduguis la jaqueta gruixuda!"

Irene: "Better take the warm jacket with you!"

\section{Claudi: "OK, ho faré."}

Claudi: "OK, I will."

(1) La Lisa i el Marcel no saben si hi haurà prou menjar per a l'esmorzar de demà.

Lisa and Marcel don't know if there will be enough food for breakfast tomorrow.

Lisa: "Ha anat a comprar avui, el Boris?"

Lisa: "Has Boris done the shopping today?"

Marcel: "No, no hi estic d'acord."

Marcel: "No, I disagree." 
(2) La mare alliçona el seu fill perquè es prepari les classes.

The mother warns her son Theo to prepare for school.

Mare: "Posa't a estudiar per a l'examen ara mateix!"

Mother: "Learn for your class exam! Now!"

Fill: "Sí, és correcte."

Son: "Yes, that's right."

(3) El Jordi i l'Úrsula parlem del seu fill durant el sopar.

Jordi and Úrsula are talking about their son during dinner.

Úrsula: "Ha d'anar a escola demà?"

Úrsula: "Does he have to go to school tomorrow?"

Jordi: "Sí, hi estic d'acord."

Jordi: "Yes, I agree."

(4) En Miquel i l'Ignasi es posen d'acord que aquest vespre en Miquel anirà a comprar.

Miquel and Ignasi arrange that Miquel will do the shopping tonight.

Ignasi: "Porta'm també un quilo de tomàquets, sisplau!"

Ignasi: "Please bring also one kilo of tomatoes!"

Miquel: "Sí, és correcte."

Miquel: "Yes, that's right."

(1) La Sílvia i la Clàudia es pregunten qui és el noi nou de la classe.

Sílvia and Clàudia are wondering who is the new boy in their class.

Sílvia: "Com es diu?"

Sílvia: "What's his name?"

Clàudia: "No, això no és així."

Clàudia: "No, that's not right." 
(2) La Sara i l'Esteve parlen del seu amic Hèctor.

Sara and Esteve are talking about their friend Harald.

Sara: "L'Hèctor s'ha comprat una nova casa."

Sara: "Hèctor has bought a new house."

Esteve: "Sí, ho faré."

Esteve: "Yes, I will."

(3) L'Helena i la Berta veuen que s'acosta en Miquel.

Helena and Berta watch Miquel coming closer.

Helena: "Té una bici nova, el Miquel?"

Helena: "Does Mirko have a new bike?"

Berta: "Sí, ja me n'ocuparé."

Berta: "Yes, I will take care of that."

(4) La Carme i la seva millor amiga van de compres juntes.

Carme and her best friend are going shopping together.

Carme: "Quin vestit m'hauria de comprar?"

Carme: "Which dress should I buy?"

Amiga: "Sí, és veritat."

Amiga: "Yes, that's true."

\section{German filler items (incl. translations)}

GOOD

(1) Werner und Monika sprechen über ihre gemeinsame Freundin Linda.

Werner and Monika are talking about their friend Linda.

Werner: „Linda hat einen schlauen Sohn.“

Werner: "Linda has a smart son."

Monika: „Nein, das stimmt nicht.“

Monika: "No, that's not right." 
(2) Mutter und Tochter besprechen den Plan für den morgigen Tag.

Mother and daughter discuss the plan for tomorrow.

Tochter: „Muss ich wirklich mein Zimmer aufräumen?“

Daughter: "Do I really have to clean up my room?"

Mutter: „Ja.“

Mother: Yes.

(3) Die Lehrerin spricht mit ihrer Kollegin über ihre gemeinsame Schülerin Claudia.

The teacher is talking to her colleague about their student Claudia.

Lehrer: „Claudia hat eine tolle Arbeit geschrieben.“

Teacher: "Claudia has written a great essay."

Kollegin: „Ja, das finde ich auch.“

Colleague: "Yes, I agree."

(4) Irene sieht, dass es draußen sehr windig ist und macht sich Sorgen um ihren Mann Klaus.

Irene notices that it is very windy outside and worries about her husband Klaus.

Irene: „Nimm lieber die warme Jacke mit!“

Irene: "Better take the warm jacket with you!"

Klaus: „OK, mache ich.“

Klaus: "OK, I will."

MEDIUM

(1) Lisa und Marcel wissen nicht, ob sie morgen noch genug Essen zum Frühstück haben werden.

Lisa and Marcel don't know if there will be enough food for breakfast tomorrow.

Lisa: „Hat Boris heute eingekauft?“

Lisa: "Has Boris done the shopping today?"

Marcel: „Nein, das finde ich nicht.“

Marcel: "No, I disagree." 
(2) Die Mutter ermahnt ihren Sohn Theo, dass er sich endlich auf die Schule vorbereitet.

The mother warns her son Theo to prepare for school.

Mutter: „Lern bitte endlich für die Klassenarbeit!“

Mother: "Learn for your class exam! Now!"

Sohn: „Ja, das stimmt.“

Son: "Yes, that's right."

(3) Georg und Ute unterhalten sich beim Abendessen über ihren Sohn.

Georg and Ute are talking about their son during dinner.

Ute: „Muss er morgen in die Schule?“

Ute: "Does he have to go to school tomorrow?"

Georg: „Das finde ich auch.“

Georg: "Yes, I agree."

(4) Manfred und Inge verabreden, dass Manfred heute Abend einkaufen geht.

Manfred and Inge arrange that Manfred will do the shopping tonight.

Inge: „Bring auch noch ein Pfund Tomaten mit!“

Inge: "Please bring also one pound of tomatoes!"

Manfred: „Ja, das stimmt.“

Manfred: "Yes, that's right."

(1) Svenja und Claudia fragen sich, wer der neue Junge in ihrer Klasse ist.

Svenja and Claudia are wondering who is the new boy in their class.

Svenja: „Was ist wohl sein Name?“

Svenja: "What's his name?"

Claudia: „Nein, das stimmt nicht.“

Claudia: "No, that's not right." 
(2) Sascha und Stefan unterhalten sich über ihren Freund Harald.

Sascha and Stefan are talking about their friend Harald.

Sascha: „Harald hat ein neues Haus gekauft.“

Sascha: "Harald has bought a new house."

Stefan: „Ja, mache ich.“

Stefan: "Yes, I will."

(3) Stefanie und Bettina sehen, wie Mirko sich ihnen nähert.

Stefanie and Bettina watch Mirko coming closer.

Stefanie: „Hat Mirko ein neues Fahrrad?“

Stefanie: "Does Mirko have a new bike?"

Bettina: „Ja, ich erledige das.“

Bettina: "Yes, I will take care of that."

(4) Carmen ist mit ihrer besten Freundin zusammen einkaufen.

Carmen and her best friend are going shopping together.

Carmen: „Welches Kleid soll ich nehmen?“

Carmen: "Which dress should I buy?"

Freundin: „Ja, das stimmt.“

Friend: "Yes, that's true." 
(C)

Additional questionnaire for Catalan informants

Aporta la informació més acurada possible a les qüestions que et plantegem.

1. Edat:

2. Sexe: Home / Dona

3. Via d'ingrés a la universitat:

Batxillerat CFGS Més grans de 25/45

4a. Ciutat de naixement:

4b. Ciutat de residència habitual:

5a. Indica a quina edat vas començar a sentir parlar català...

Edat

...a casa:

... l'escola:

5b. Indica a quina edat vas començar a parlar català...

Edat

...a casa:

...a l'escola:

6. Com vas aprendre el català? (marca totes les opcions que creguis convenient)

(principalment sobretot ocasionalment) interactuant amb familiars i amics.

(principalment sobretot ocasionalment) a l'escola.

(principalment sobretot ocasionalment) amb cursos de català.

7. Quina va ser la llengua majoritària dels diferents nivells d'ensenyament?

Primària:

ESO:

Batxillerat/CFGS:

Universitat: 
8. Ordena totes les llengües que saps, de millor a pitjor (pots col·locar més d'una llengua a cada categoria).

\begin{tabular}{|l|l|l|l|l|l|}
\hline & Molt poc & Poc & Bé & Molt bé & Natiu \\
\hline 1. & & & & & \\
\hline 2. & & & & & \\
\hline 3. & & & & & \\
\hline 4. & & & & & \\
\hline 5. & & & & & \\
\hline
\end{tabular}

9. Fes una estimació en hores de l'ús que fas del català, el castellà o d'altres llengües al llarg del dia segons les activitats següents:

\begin{tabular}{|c|c|c|c|c|}
\hline & català & castellà & & \\
\hline Escoltar la ràdio/mirar la TV: & h. & h. & h. & h. \\
\hline Internet i xarxes socials: & h. & h. & h. & h. \\
\hline Llegir/escriure per feina: & h. & h. & h. & h. \\
\hline
\end{tabular}

10. Fes una estimació de les hores que parles el català, el castellà o d'altres llengües al llarg del dia:

català:

hores

castellà:

una altra llengua (quina?):

11. De totes les llengües que saps, quina és la que prefereixes fer servir en les situacions següents?

a casa

a la feina

en una festa amb amics

de manera general

12. Si has viscut en altres països, indica el nom del país, el temps que hi vas viure i les llengües que hi vas aprendre o estudiar.

\section{References}

Aboh, Enoch O., 2010. Information structuring begins with the numeration. Iberia 2, 12-42.

Bayer, Josef, Trotzke, Andreas, 2015. The derivation and interpretation of left peripheral discourse particles. In: Bayer, J., Hinterhölzl, R., Trotzke, A. (Eds.), Discourse-oriented Syntax. John Benjamins, Amsterdam, pp. 13-40.

Beltrama, Andrea, Trotzke, Andreas, 2019. Conveying emphasis for intensity: lexical and syntactic strategies. Lang. Linguist. Compass 13 (7), 1-13. https:// doi.org/10.1111/lnc3.12343.

Bennis, Hans, 1998. Exclamatives! Ling. Neth. 15 (1), 27-40.

Castroviejo Miró, Elena, 2006. Wh-exclamatives in Catalan. PhD Dissertation. Universitat de Barcelona.

Ceong, Hailey Hyekyeong, 2019. The Morphosyntax of Clause Typing: Single, Double, Periphrastic, and Multifunctional Complementizers in Korean. PhD Dissertation. University of Victoria.

Corr, Alice, 2018. 'Exclamative'and ‘quotative'illocutionary complementisers in Catalan, European Portuguese and Spanish. Lang. Contrast 18 (1), 69-98. https://doi.org/10.1075/lic.00004.cor.

d'Avis, Franz Josef, 2016. Different languages - different sentence types? On exclamative sentences. Lang. Linguist. Compass 10 (4), 159-175. https://doi. org/10.1111/lnc3.12181.

D'Hertefelt, Sarah, 2018. Insubordination in Germanic: A Typology of Complement and Conditional Constructions. De Gruyter, Berlin.

de Marneffe, Marie-Catherine, Tonhauser, Judith, 2019. Inferring meaning from indirect answers to polar questions: the contribution of the rise-fall-rise contour. In: Zimmermann, M., von Heusinger, K., Onea, E. (Eds.), Questions in Discourse. Brill, Leiden, pp. 132-163. https://doi.org/10.1163/ 9789004378322_006.

Degen, Judith, Trotzke, Andreas, Scontras, Gregory, Wittenberg, Eva, Goodman, Noah D., 2019. Definitely, maybe: a new experimental paradigm for investigating the pragmatics of evidential devices across languages. J. Pragmat. 140, 33-48. https://doi.org/10.1016/j.pragma.2018.11.015. 
Delsing, Lars Olof, 2010. Exclamatives in scandinavian. Stud. Ling. 64 (1), 16-36. https://doi.org/10.1111/j.1467-9582.2010.01168.x.

Eckardt, Regine, 2007. Inherent focus on wh-phrases. In: McNally, L., Puig-Waldmüller, E. (Eds.), Proceedings of Sinn und Bedeutung 11. Universitat Pompeu Fabra, Barcelona, pp. 209-228.

Espinal, M.Teresa, Tubau, Susagna, 2019. Response systems: the syntax and semantics of fragment answers and response particles. Annu. Rev. Linguist. 5 (1), 261-287. https://doi.org/10.1146/annurev-linguistics-011718-012613.

Evans, Nicholas, 2007. Insubordination and its uses. In: Nikolaeva, I. (Ed.), Finiteness: Theoretical and Empirical Foundations. Oxford University Press, Oxford, pp. 366-431.

Feldhausen, Ingo, Villalba, X., 2020. Modality and information structure: focus, dislocation, interrogative and exclamatory sentences. In: Argenter, J.A., Lüdtke, J. (Eds.), Manual of Catalan Linguistics. De Gruyter, Berlin, pp. 247-270. https://doi.org/10.1515/9783110450408-009.

Gérard-Naef, Josselyne, 1980. L'exclamation en français: la syntaxe des phrases et des expressions exclamatives. Tübingen, Max Niemeyer:

Gertken, Libby M., Amengual, Mark, Birdsong, David, 2014. Assessing language dominance with the bilingual language profile. In: Leclercq, P., Edmonds, A., Hilton, H. (Eds.), Measuring L2 Proficiency. Multilingual Matters, Bristol, pp. 208-225. https://doi.org/10.21832/9781783092291-014.

Gras, Pedro, Sansiñena, María Sol, 2017. Exclamatives in the functional typology of insubordination: evidence from complement insubordinate constructions in Spanish. J. Pragmat. 115, 21-36. https://doi.org/10.1016/j.pragma.2017.04.005.

Grice, H. Paul, 1975. Logic and conversation. In: Cole, P., Morgan, J. (Eds.), Speech Acts. Academic Press, New York, pp. 41-58.

Grice, H. Paul, 1981. Presupposition and conversational implicature. In: Cole, P. (Ed.), Radical Pragmatics. Academic Press, New York, pp. 183-198.

Grimshaw, Jane, 1979. Complement selection and the lexicon. Ling. Inq. 10 (2), 279-326.

Haegeman, Liliane, Weir, Andrew, 2015. The cartography of yes and no in West Flemish. In: Bayer, J., Hinterhölzl, R., Trotzke, A. (Eds.), Discourse-oriented Syntax. John Benjamins, Amsterdam, pp. 175-210.

Holmberg, Anders, 2013. The syntax of answers to polar questions in English and Swedish. Lingua 128, 31-50. https://doi.org/10.1016/j.lingua.2012.10.018.

Holmberg, Anders, 2015. The Syntax of Yes and No. Oxford University Press, Oxford and New York.

Holtgraves, Thomas, 1998. Interpreting indirect replies. Cognit. Psychol. 37, 1-27. https://doi.org/10.1006/cogp.1998.0689.

Horvath, Julia, 2010. "Discourse features", syntactic displacement and the status of contrast. Lingua 120, 1346-1369. https://doi.org/10.1016/j.lingua.2008. 07.011.

Newmeyer, Frederick J., 2009. On split CPs and the 'perfectness' of language. In: Shaer, B., Cook, P., Frey, W., Maienborn, C. (Eds.), Dislocated Elements in Discourse: Syntactic, Semantic, and Pragmatic Perspectives. Routledge, New York \& London, pp. 114-140.

Prieto, Pilar, Rigau, Gemma, 2007. The Syntax-Prosody Interface: Catalan interrogative sentences headed by que. J. Port. Linguist. 6 (2), 29-59. https://doi. org/10.5334/jpl.139.

Ramchand, Gillian, Svenonius, Peter, 2014. Deriving the functional hierarchy. Lang. Sci. 46, 152-174.

Rett, Jessica, 2011. Exclamatives, degrees and speech acts. Ling. Philos. 34, 411-442.

Rizzi, Luigi, 1997. The fine structure of the left periphery. In: Haegeman, L. (Ed.), Elements of Grammar. Kluwer, Dordrecht, pp. 281-337. https://doi.org/10. 1007/978-94-011-5420-8_7.

Rizzi, Luigi, 2014. Syntactic cartography and the syntacticisation of scope-discourse semantics. In: Reboul, A. (Ed.), Mind, Values, and Metaphysics. Springer, Berlin, pp. 517-533. https://doi.org/10.1007/978-3-319-05146-8_30.

Trotzke, Andreas, 2019. Approaching the pragmatics of exclamations experimentally. In: Ronai, E., et al. (Eds.), Proceedings of the 54th Annual Meeting of the Chicago Linguistic Society (CLS 54). Chicago Linguistic Society, Chicago, pp. 527-540.

Trotzke, Andreas. in press. How cool is that! A new 'construction' and its theoretical challenges. J. Comp. Germa. Ling.

Trotzke, Andreas \& Villalba, Xavier. in press. Expressive insubordination: a cross-linguistic study on that-exclamatives. In: Trotzke, A. \& Villalba, X. (Eds.), Expressive Meaning across Linguistic Levels and Frameworks. Oxford, Oxford University Press.

Trotzke, Andreas, Zwart, Jan-Wouter, 2014. The complexity of narrow syntax: minimalism, representational economy, and simplest Merge. In: Newmeyer, F. J., Preston, L.B. (Eds.), Measuring Grammatical Complexity. Oxford University Press, Oxford, pp. 128-147.

Truckenbrodt, Hubert, 2006. On the semantic motivation of syntactic verb movement to C in German. Theor. Ling. 32, 257-306. https://doi.org/10.1515/TL. 2006.018.

Truckenbrodt, Hubert, 2013. An analysis of prosodic F-effects in interrogatives: prosody, syntax and semantics. Lingua 124, 131-175.

Villalba, Xavier, 2003. An exceptional exclamative sentence type in Romance. Lingua 113 (8), 713-745. https://doi.org/10.1016/S0024-3841(02)00117-1.

Walker, Traci, Drew, Paul, Local, John, 2011. Responding indirectly. J. Pragmat. 43, 2434-2451.

Wiltschko, Martina, 2018. Response particles beyond answering. In: Bailey, L.R., Sheehan, M. (Eds.), Order and Structure in Syntax. Language Science Press, Berlin, pp. 241-279.

Zanuttini, Raffaella, Portner, Paul, 2003. Exclamatives clauses: at the syntax-semantics interface. Lang. 79 (1), 39-81.

Prof. Dr. Andreas Trotzke is Außerplanmäßiger Professor in the Department of Linguistics, University of Konstanz and Research Fellow at the Autonomous University of Barcelona. Trotzke is General Editor of the journal Pedagogical Linguistics (John Benjamins). He got his PhD from the University of Freiburg in 2010 and has been a lecturer at the University of Potsdam (2009-2011) and a Postdoc at the University of Konstanz (2011-2016). He has been awarded several Invited Professorships and Visiting Scholarships, among them a 1-year scholarship at Stanford University (2016-2017), the prestigious International Chair 2017 Empirical Foundations of Linguistics at Université Sorbonne Paris Cité/CNRS, and an IDEX Professorship (1re classe) at the Université de Bordeaux. His areas of expertise include pragmatics, the syntax-pragmatics interface, psycholinguistics, and language education, and he has published his research in many top-ranked journals, including Journal of Pragmatics, Linguistics, Journal of Linguistics, and Lingua. 